\title{
PENGARUH DOSIS PUPUK NPK TERHADAP PERTUMBUHAN DAN HASIL BAWANG MERAH, KABUPATEN JAYAPURA, PAPUA
}

\section{(Effect Of NPK Fertilizer Dosage On Growth And Yield Of Shallot, District Jayapura, Papua)}

\author{
Rohimah H.S. Lestari dan Fransiskus Palobo \\ Balai Pengkajian Teknologi Pertanian (BPTP) Papua \\ Jl. Yahim Sentani - Jayapura Telp.(0967) 592179 faks. 591235. \\ E-mail: rohimahhsl@gmail.com
}

Article Submitted : 03-04-2019

Article Accepted : 06-05-2019

\begin{abstract}
Shallots is one of the important commodities in Indonesia. Demand for these commodities always increases along with population growth. To fulfill this demand, the production of shallots must always be increased. One way to increase the production of shallots is by fertilizing. This study aims to determine the dosage of NPK fertilizer which gives the best results for the growth and yield of shallots. The study was carried out in Sentani District, Papua Province, from November 2016 until March 2017.The study used the Randomized Complete Block Design (RCBD) with three treatments NPK Phonska fertilization (NPK 15-15-15 composition) and four repplication. NPK fertilizer used were: 1) NPK $300 \mathrm{~kg} / \mathrm{ha}$, 2) $250 \mathrm{~kg} / \mathrm{ha}$, and 3) $200 \mathrm{~kg} / \mathrm{ha}$. The meterials used were shaloot bulbs Keta Monca cultivar. The plot size was 1 x 5 m, with a spacing of $15 \times 15 \mathrm{~cm}$. NPK fertilizer was given at the age of 14 and 30 days after planting respectively with the dose of $1 / 2$. The variables observed were plant height, leaf number, bulbs number per sample, diameter of bulbs, dry weight bulb per hectare The results showed that the treatment of NPK fertilizer dosage did not give a significant effect on almost all observation variables except on the dry weight of eskip bulb, where the treatment dose of $200 \mathrm{~kg} / \mathrm{ha}$ NPK fertilizer gave the highest yield compared to other treatments. When observed from the growth components and production components, the dose of NPK fertilizer $200 \mathrm{~kg} / \mathrm{ha}$ is the most consistent to provide better growth and yield.
\end{abstract}

Key words: shallot, dosage, fertilizer, NPK.

\section{PENDAHULUAN}

Bawang merah merupakan komoditi hortikultura yang memiliki nilai ekonomis yang cukup tinggi. Komoditas ini banyak dibutuhkan terutama sebagai pelengkap bumbu masakan guna menambah cita rasa dan kenikmatan masakan, selain itu dapat digunakan sebagai bahan baku obat-obatan, memiliki banyak vitamin dan berperan sebagai aktivator enzim di dalam tubuh. (Napitupulu et al, 2010; Jurgiel dan Janina, 2008; Sufyati et al, 2006). Permintaan komoditas ini selalu meningkat seiring dengan pertambahan jumlah penduduk. Untuk memenuhi permintaan tersebut maka produksi bawang merah harus selalu ditingkatkan. Salah satu cara untuk meningkatkan produksi bawang merah adalah pemupukan. Teknologi pemupukan merupakan salah satu faktor penentu di dalam meningkatkan produksi tanaman (Putra, 2012).

Daya adaptasi bawang merah termasuk luas karena dapat tumbuh dan menghasilkan umbi di dataran rendah hingga dataran tinggi. Keragaman tanah dan lingkungan yang 
cukup tinggi di Indonesia menyebabkan kebutuhan hara NPK berbeda dari satu lokasi ke lokasi lainnya. Untuk menentukan kebutuhan hara NPK spesifik lokasi secara tepat pada bawang merah maka perlu diuji lebih lanjut untuk mendapatkan hasil yang optimum. Pada umumnya bawang merah banyak diusahakan di dataran rendah pada jenis tanah Alluvial (71\%), sedangkan di dataran medium pada jenis tanah Latosol (16\%), dan di dataran tinggi pada jenis tanah Andisol atau asosiasi Andisol-Latosol (13\%). (Sumarni et al, 2012).

Tanaman perlu input pupuk NPK sebagai sumber energi untuk proses pertumbuhannya (Gardner et al. 1985). Unsur $\mathrm{N}$, P, dan $\mathrm{K}$ merupakan faktor penting dan harus selalu tersedia bagi tanaman, karena berfungsi sebagai proses metabolisme dan biokimia sel tanaman (Nurtika \& Sumarni 1992). Nitrogen sebagai pembangun asam nukleat, protein, bioenzim, dan klorofil (Sumiati 1989). Fosfor sebagai pembangun asam nukleat, fosfolipid, bioenzim, protein, senyawa metabolik, dan merupakan bagian dari ATP yang penting dalam transfer energi (Sumiati 1983). Kalium mengatur keseimbangan ion-ion dalam sel, yang berfungsi dalam pengaturan berbagai mekanisme metabolik seperti fotosintesis, metabolisme karbohidrat dan translokasinya, sintetik protein berperan dalam proses respirasi dan meningkatkan ketahanan tanaman terhadap serangan hama dan penyakit (Hilman \& Noordiyati 1988).

Aplikasi pupuk NPK dapat dilakukan dengan berbagai cara yaitu bisa dengan menggunakan pupuk tunggal maupun pupuk majemuk. Penggunaan pupuk majemuk dapat menutup kekurangan pupuk tunggal. Pupuk majemuk memiliki keunggulan dibandingkan dengan pupuk tunggal, yaitu mengandung lebih dari satu jenis hara, lebih praktis dalam pemesanan, transportasi, penyimpanan, dan aplikasinya di lapangan. Keuntungan lain dari penggunaan pupuk majemuk tersebut adalah lebih homogen dalam penyebaran pupuk (Vidya et al, 2016). Pupuk NPK (nitrogen phosphate kalium) merupakan pupuk majemuk cepat tersedia yang paling dikenal saat ini. Salah satu jenis pupuk yang mengandung unsur hara N, P, K dan banyak dijual di kios pertanian saat ini adalah pupuk Phonska. Pupuk Phonska merupakan pupuk majemuk yang mengandung unsur hara primer $\mathrm{N}, \mathrm{P}$ dan $\mathrm{K}$ dengan komposisi NPK $15-15-15$ (mengandung $15 \% \mathrm{~N}, 15 \% \mathrm{P}_{2} 0_{5}$ dan $15 \% \mathrm{~K}_{2} 0$ ). Keberadaan pupuk majemuk ini bisa menjadi salah satu alternatif di tengah kelangkaan pupuk SP36 yang terjadi akhirakhir ini dan mahalnya pupuk Kalium ditingkat petani. Penggunaan pupuk NPK Phonska $250 \mathrm{~kg} / \mathrm{ha}+2,5$ ton /ha pupuk organik (Petroganik) dapat meningkatkan hasil umbi segar per tanaman dan hasil umbi kering pertanaman (Suwandi et al. 2015)

Agar tercapai efisiensi dalam penggunaannya, maka penggunaan pupuk NPK perlu diuji di lapang untuk mendapatkan dosis yang tepat untuk meningkatkan pertumbuhan dan hasil bawang merah. Tujuan dari penelitian ini adalah untuk menentukan dosis yang tepat bagi pertumbuhan dan hasil tanaman bawang merah.

\section{METODE PENELITIAN}

Penelitian dilaksanakan pada bulan Pebruari-April 2017 di Distrik Sentani, Kabupaten Jayapura, Provinsi Papua. Rancangan percobaan menggunakan rancangan acak kelompok faktor tunggal dengan tiga perlakuan dosis pemupukan NPK Phonska (komposisi NPK 15-15-15 ) yaitu: 1) NPK $300 \mathrm{~kg} / \mathrm{ha}, 2) 250 \mathrm{~kg} / \mathrm{ha}$, dan 3) 200 $\mathrm{kg} / \mathrm{ha}$. Semua perlakuan diulang sebanyak 4 kali. Varietas bawang merah yang digunakan adalah varietas Keta Monca. Ukuran petak percobaan masing-masing perlakuan adalah 1 x $5 \mathrm{~m}$, dengan jarak tanam $15 \times 15 \mathrm{~cm}$. Pemupukan dilakukan pada umur 14 dan 30 hari setelah tanam (HST) masing-masing setengah dosis perlakuan.

Peubah yang diamati adalah komponen pertumbuhan dan produksi yaitu: 
tinggi tanaman $(\mathrm{cm})$, jumlah daun, jumlah umbi, diameter umbi $(\mathrm{cm})$, bobot umbi/tanaman (g), bobot kering eskip per hektar (t/ha). Data hasil kajian dianalisis dengan sidik ragam, jika hasil analisis ragam berbeda nyata maka dilanjutkan dengan Uji Duncan (DMRT) pada taraf 5\%.

\section{HASIL DAN PEMBAHASAN}

\section{Kondisi Wilayah dan Iklim}

Menurut data BPS Kabupaten Jayapura (2018), Kabupaten Jayapura yang terdiri dari 19 distrik terletak diantara $139^{\circ}$ $140^{\circ}$ Bujur Timur dan diantara $2^{0}-3^{0}$ Lintang Selatan. Distrik Kaureh dengan luas 4.537,9
$\mathrm{Km}^{2}$ merupakan distrik terluas di Kabupaten Jayapura atau sekitar 24,88 persen dari luas keseluruhan Kabupaten Jayapura dan distrik Sentani Barat merupakan distrik yang luasnya terkecil dengan luas sekitar 129,2 $\mathrm{Km}^{2}$ atau sekitar 0,74 persen dari luas Kabupaten Jayapura.

Keadaan iklim di Papua sangat dipengaruhi oleh topografi daerah. Sedangkan kondisi iklimnya terbilang ekstrim karena sering berubah-rubah. Besarnya curah hujan mempengaruhi kadar air tanah, aerasi tanah dan kelembaban udara. Gambaran rataan kisaran curah hujan dan hari hujan tertera pada Gambar 1.

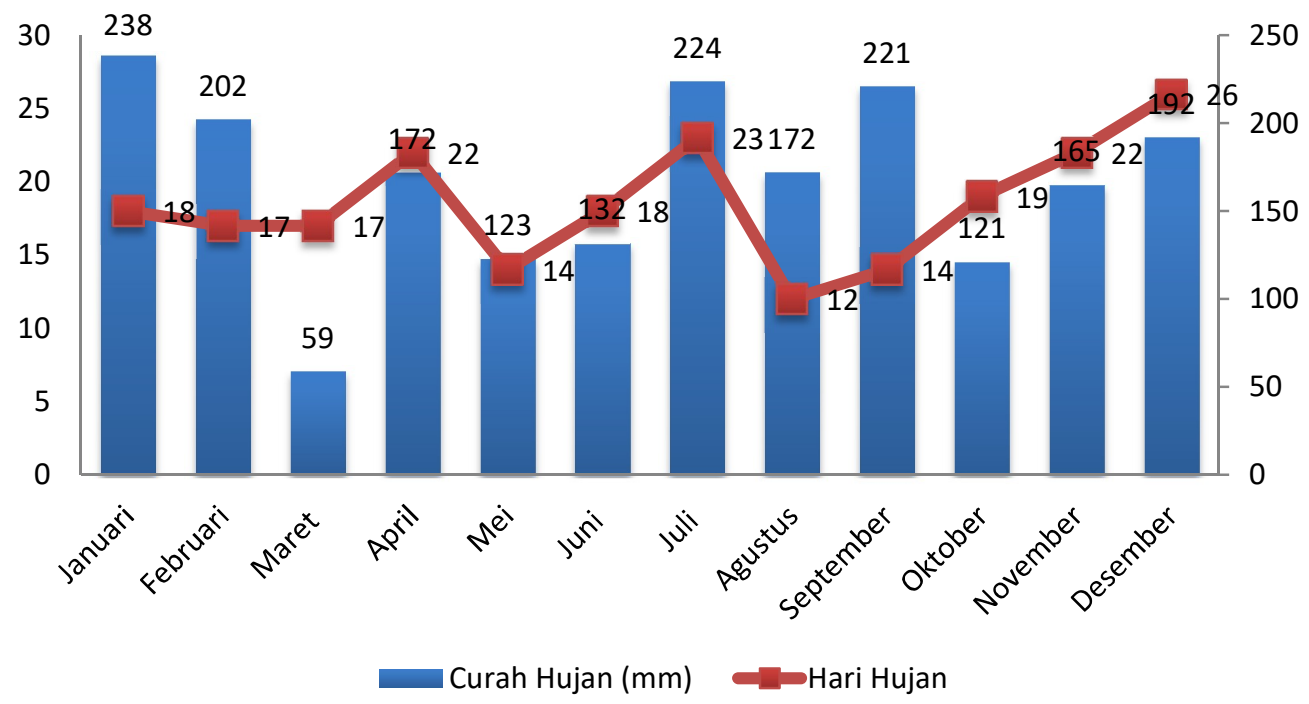

Gambar 1. Kisaran curah hujan dan hari hujan Kabupaten Jayapura Tahun 2017.

Sumber: Badan Meteorologi Klimatologi dan Geofisika Wilayah V Jayapura, 2018

Selama pelaksanaan penelitian dari bulan Februari sampai dengan April, curah hujan berkisar antara 59-202 $\mathrm{mm} /$ bulan dan jumlah hari hujan 17-18 hari. Sedangkan suhu berkisar antara $24,9-32,4^{\circ} \mathrm{C}$. Kondisi iklim tersebut menunjukkan bahwa bawang merah dapat tumbuh dan berkembang dengan baik di lokasi penelitian. Menurut Balitsa (2010), suhu lingkungan yang dibutuhkan untuk pertumbuhan normal bawang merah pada suhu $25-35^{\circ} \mathrm{C}$ dengan curah hujan antara 300-2500 mm/tahun.

\section{Komponen Pertumbuhan}

Pengukuran tinggi tanaman dan jumlah daun dilakukan pada saat 30 HST dan saat panen. Tinggi tanaman merupakan ukuran tanaman yang sering diamati sebagai indikator untuk pengaruh lingkungan atau perlakuan yang diberikan. Menurut Sitompul dan Guritno (1995), tinggi tanaman 
merupakan parameter yang paling mudah dilihat. Hasil analisis sidik ragam tinggi tanaman 30 HST dan saat panen terhadap perlakuan dosis NPK dapat dilihat pada Tabel 1.

Tabel 1. Pengaruh dosis pupuk NPK terhadap tinggi tanaman $(\mathrm{cm})$ pada umur 30 HST dan saat panen

\begin{tabular}{lccc}
\hline & Perlakuan & 30 hst $(\mathrm{cm})$ & Saat panen $(\mathrm{cm})$ \\
\hline NPK 200 & $22.87 \mathrm{a}$ & $27.12 \mathrm{a}$ \\
NPK 250 & $23.88 \mathrm{a}$ & $26.12 \mathrm{a}$ \\
& NPK 300 & $23.19 \mathrm{a}$ & $26.83 \mathrm{a}$ \\
\hline KK\% & & 7.00 & 4.41 \\
\hline
\end{tabular}

Keterangan: Angka sekolom yang diikuti oleh huruf yang sama tidak beda nyata pada taraf uji DMRT 5\%

Dari Tabel 1 dapat dilihat bahwa perlakuan dosis NPK tidak memberikan pengaruh yang nyata dalam meningkatkan tinggi tanaman bawang merah. Tinggi tanaman pada 30 HST dan saat panen memiliki tinggi yang hampir sama. Rata-rata tinggi tanaman varietas ini tidak terlalu tinggi yaitu 26,69 $\mathrm{cm}$, hal ini sesuai dengan deskripsinya yaitu berkisar antara $25-44 \mathrm{~cm}$.

Selain tinggi tanaman, jumlah daun juga merupakan parameter pertumbuhan tanaman yang penting untuk diamati, karena daun merupakan organ tanaman untuk penyerapan dan pengubahan energi cahaya matahari melalui proses fotosintesis, dimana hasil dari proses tersebut sebagai sumber penghasil makanan yang digunakan untuk pertumbuhan. Sitompul dan Guritno (1995), menyatakan bahwa pengamatan daun sangat diperlukan sebagai indikator pertumbuhan dan juga sebagai data penunjang untuk menjelaskan proses pertumbuhan yang terjadi seperti pada pembentukan biomassa tanaman. Peningkatan jumlah daun dapat meningkatkan luas daun sehingga berpotensi meningkatkan pertumbuhan dan hasil tanaman.

Tabel 2. Pengaruh Dosis Pupuk NPK terhadap Jumlah Daun pada Umur 30 HST dan Saat Panen

\begin{tabular}{ccc}
\hline Perlakuan & 30 hst $(\mathrm{cm})$ & Saat panen $(\mathrm{cm})$ \\
\hline NPK 200 & $3,46 \mathrm{a}$ & $9,08 \mathrm{a}$ \\
NPK 250 & $3,00 \mathrm{a}$ & $7,75 \mathrm{a}$ \\
NPK 300 & $2,88 \mathrm{a}$ & $8,08 \mathrm{a}$ \\
\hline KK\% & 16,96 & $8,43 \mathrm{a}$ \\
\hline
\end{tabular}

Keterangan: Angka sekolom yang diikuti oleh huruf yang sama tidak beda nyata pada taraf uji DMRT $5 \%$

Pada Tabel 2 menunjukkan bahwa jumlah daun tidak dipengaruhi secara nyata oleh dosis pemupukan. Secara statistik, semua perlakuan mempunyai jumlah daun yang sama banyak, namun berdasarkan nilai rata-ratanya perlakuan dosis pupuk NPK 200 $\mathrm{kg} / \mathrm{ha}$ mempunyai jumlah daun yang lebih banyak dibanding perlakuan pemupukan lainnya baik itu pada umur 30 hst maupun saat panen. Jumlah daun yang lebih banyak secara tidak langsung akan mempengaruhi hasil tanaman bawang merah. Terlihat dari umbi yang dihasilkan pada perlakuan tersebut memiliki bobot kering umbi eskip paling tinggi dibanding perlakuan lainnya (Tabel 3). 


\section{Komponen Produksi}

Bobot kering umbi eskip dipengaruhi oleh beberapa komponen hasil yaitu jumlah umbi, diameter umbi dan bobot umbi per rumpun. Berdasarkan hasil analisis sidik ragam pada Tabel 3 menunjukkan bahwa perlakuan dosis pupuk NPK tidak memberikan pengaruh yang nyata dalam meningkatkan jumlah umbi, diameter umbi dan bobot umbi per rumpun namun berpengaruh nyata pada bobot kering umbi eskip

Tabel 3. Pengaruh Dosis Pupuk NPK terhadap Jumlah Umbi per Rumpun, Diameter Umbi (cm), Bobot Umbi/Rumpun (g), dan bobot kering umbi eskip ( $\mathrm{t} / \mathrm{ha}$ )

\begin{tabular}{ccccc}
\hline Perlakuan & $\begin{array}{c}\text { Jumlah } \\
\text { umbi/rumpun }\end{array}$ & $\begin{array}{c}\text { Diameter umbi } \\
(\mathrm{cm})\end{array}$ & $\begin{array}{c}\text { Bobot umbi } \\
\text { /rumpun }(\mathrm{g})\end{array}$ & $\begin{array}{c}\text { Bobot kering umbi eskip } \\
(\mathrm{t} / \mathrm{ha})\end{array}$ \\
\hline NPK 200 & $7.33 \mathrm{a}$ & $2.80 \mathrm{a}$ & $58.24 \mathrm{a}$ & $8.30 \mathrm{a}$ \\
NPK 250 & $7.66 \mathrm{a}$ & $2.44 \mathrm{a}$ & $48.96 \mathrm{a}$ & $5.82 \mathrm{~b}$ \\
NPK 300 & $8.12 \mathrm{a}$ & $2.43 \mathrm{a}$ & $55.54 \mathrm{a}$ & $5.22 \mathrm{~b}$ \\
\hline KK\% & 11.46 & 7.73 & 9.78 & 21.61 \\
\hline
\end{tabular}

Keterangan: Angka sekolom yang diikuti oleh huruf yang sama tidak beda nyata pada taraf uji DMRT 5\%

Tabel 3 menunjukan bahwa jumlah umbi bawang merah pada semua perlakuan tidak berbeda nyata. Namun jika dilihat dari nilai rata-ratanya terlihat bahwa perlakuan dosis NPK $300 \mathrm{~kg} / \mathrm{ha}$ memiliki jumlah umbi per rumpun yang lebih banyak dibanding dengan perlakuan lainnya yaitu 8,12 . Namun jumlah umbi yang lebih banyak tidak menyebabkan meningkatnya bobot kering jemur umbi. Hal ini tidak sesuai dengan pernyataan bahwa jumlah umbi per rumpun berhubungan dengan produksi umbi di mana semakin banyak umbi per rumpun maka semakin tinggi produksinya, justru perlakuan dosis $200 \mathrm{~kg} / \mathrm{ha}$ yang memberikan bobot kering jemur paling tinggi dibanding perlakuan lainnya, sedangkan perlakuan dosis pupuk NPK 250 dan dosis pupuk 300 $\mathrm{kg} / \mathrm{ha}$ mempunyai bobot kering umbi eskip yang tidak berbeda nyata. Tingginya bobot kering umbi eskip pada perlakuan dosis 200 $\mathrm{kg} / \mathrm{ha}$ karena didukung rata-rata diameter umbi dan bobot umbi per rumpun yang lebih tinggi dibanding perlakuan lainnya.

Secara umum perlakuan pemupukan dosis NPK $200 \mathrm{~kg} / \mathrm{ha}$ memberikan pengaruh yang lebih baik dalam meningkatkan pertumbuhan dan hasil tanaman bawang merah. Terlihat dari komponen pertumbuhan dan hasil yang lebih baik dari perlakuan dosis pupuk NPK $250 \mathrm{~kg} / \mathrm{ha}$ dan $300 \mathrm{~kg} / \mathrm{ha}$ (Tabel 1, 2 dan 3). Hal ini mengindikasikan bahwa dosis $200 \mathrm{~kg} /$ ha merupakan dosis yang tepat untuk tanaman bawang merah. Karena unsur hara $\mathrm{N}, \mathrm{P}$, dan $\mathrm{K}$ tersedia dalam jumlah yang cukup untuk tanaman. Suatu tanaman dapat tumbuh subur apabila scgala elemcn yang dibutuhkan bcrada dalam keadaan cukup dan sesuai untuk diserap tanaman. Kekurangan hara $\mathrm{N}$ dapat membatasi pembelahan dan pembesaran sel (Sumiati \& Gunawan 2007) serta pembentukan klorofil sehingga pertumbuhan tanaman menjadi terhambat dan daunnya kekuningan (Nurhayati et al. 1986). Defisiensi P menyebabkan pertumbuhan dan perkembangan tanaman lambat, lemah, dan kerdil (Suwandi et al. 2015), sedangkan kekurangan unsur K akan menghambat proses-proses penting seperti transportasi gula dari daun ke umbi, aktivitas enzim, sintesis protein, dan pembesaran sel, yang pada akhirnya akan menentukan hasil dan kualitas hasil (William \& Kafkafi ,1998)

\section{KESIMPULAN}

Perlakuan pemberian dosis pupuk NPK tidak memberikan pengaruh yang nyata di hampir semua variabel pengamatan kecuali pada bobot kering umbi eskip, 
dimana perlakuan dosis pupuk NPK 200 $\mathrm{kg} / \mathrm{ha}$ memberikan hasil yang paling tinggi dibanding perlakuan lainnya. Bila diperhatikan dari komponen pertumbuhan maupun komponen produksi, dosis pupuk NPK $200 \mathrm{~kg} /$ ha paling konsisten memberikan pertumbuhan dan hasil yang lebih baik.

\section{DAFTAR PUSTAKA}

Balitsa. 2010. Budidaya Bawang Merah. Pusat Penelitian Dan Pengembangan Hortikultura.

BMKG. 2018. Data Curah Hujan Kabupaten Jayapura. Jayapura

Gardner, F. P., R. B. Pearce, and R. L. Mitchell. 1985. Physiology Of Crop Plants. The Iowa State University Press. Ames, Iowa 50010. USA. p. 82-84

Hilman, Y dan I. Noordiyati. 1988. Pengujian Pemupukan $P$ Dan $K$ Berimbang Pada Tanaman Bawang Putih Di Tanah Sawah. Bul. Penel. Hort. 16(1): 48-54.

Jurgiel, G. and S. Janina. 2008. The Effect Of Nitrogen Fertilization On Content Of Microelements In Selected Onions. J. Elementol. 13(2): 227-234

Napitupulu, D dan L. Winarto. 2010. Pengaruh Pemberian Pupuk N Dan K Terhadap Pertumbuhan Dan Produksi Bawang Merah. J. Hort. 20(1): 27-35

Nurhayati., H. Nyapa., M.Y. Lubis., A.M. Nugroho., S.G. Diha., M.A., G.B. Hong \& H.H. Bailey. 1986. DasarDasar Ilmu Tanah, Penerbit Universitas Lampung: 212-302 pp

Nurtika, N dan N. Sumarni. 1992. Pengaruh Sumber, Dosis Dan Waktu Aplikasi
Pupuk Kalium Terhadap Pertumbuhan Dan Hasil Tomat. Bul Penel. Hort. 22 (1): 96-101.

Putra, S. 2012. Pengaruh Pupuk NPK Tunggal, Majemuk, Dan Pupuk Daun Terhadap Peningkatan Produksi Padi Gogo Varietas Situ Patenggang. Jurnal Agrotrop. 2(1): 55-61

Vidya., Suparman dan Karjo. 2016. Kajian Pupuk Majemuk PK Terhadap Produksi Bawang Merah Di Lahan Berpasir Dataran Rendah. Prosiding Seminar Nasional Inovasi Teknologi Pertanian: 890-895.

Sitompul, S. M dan B. Guritno. 1995. Analisis Pertumbuhan Tanaman. UGM Press. Yogyakarta. 412 pp

Sufyati, Y., S. Imran A.K., dan Fikrinda. 2006. Pengaruh Ukuran Fisik Dan Jumlah Umbi Per Lubang Terhadap Pertumbuhan Dan Hasil Bawang Merah (Allium ascalonicum L.). J.Floratek 2: 43 -54

Sumarni, N., R. Rosliani, dan R.S. Basuki. 2012. Respons Pertumbuhan, Hasil Umbi, Dan Serapan Hara NPK Tanaman Bawang Merah Terhadap Berbagai Dosis Pemupukan NPK Pada Tanah Alluvial. J. Hort. 22(4): 366-375

Sumiati, E .1983. Pengaruh Zat Pengatur Tumbuh Dan Pupuk Daun, Biokimia Terhadap Hasil Tanaman Tomat (Lysopersicum Esculentum Mill L.). Bul. Penel. Hort. 10(3) : 21-27.

Sumiati, E. 1989. Pengaruh Mulsa Jerami, Naungan Dan Zat Pengatur Tumbuh Terhadap Hasil Buah Tomat Kultivar Berlian. Bul. Penel. Hort.18(2): 1831 . 
Sumiati, E dan O.S. Gunawan. 2007. Aplikasi Pupuk Hayati Mikoriza Untuk Meningkatkan Serapan Unsur Hara NPK Serta Pengaruhnya Terhadap Hasil Dan Kualitas Hasil Bawang Merah. J. Hort. 17(1): 34-42.

Suwandi., G.A. Sopha dan M. P. Yufdy. 2015. Efektivitas Pengelolaan Pupuk Organik, NPK, Dan Pupuk Hayati Terhadap Pertumbuhan Dan Hasil
Bawang Merah. J. Hort. 25 (3): 208221

William, L and U. Kafkafi. 1998. Intake And Translocation Of Potassium And Phosphate By Tomatoes By Late Spray Of $\mathrm{KH}_{2} \mathrm{PO}_{4}(\mathrm{MKP})^{\prime}, \mathrm{NRC}$. Cairo Egypt, Proceeding of symposium of fertilization. Atechnique to improve production and decrease pollutan. 